\title{
THE VARIATION OF COTTON OIL AND MISCELLA PARAMETERS IN THE ADSORBTION REFINING PROCESS
}

Fayoza Suvanova, Jasur Farmonov, Oybek Ikromov, Azimjon Akhmedov, Karshi EngineeringEconomics institute, goldenwater66@mail.ru

\begin{abstract}
With the purpose of decreasing the content of the related substances in plant oils, subjected to hydrogenation, the technology stipulates their refining. Alkaline reagent is primarily used for implementing this process. However, some substances, related to the oil and the solvent (if it is used) don't react with alkali and form new complex compounds which pass into the oil content. This permits hydrogenation. Though their amount, at first glance, is not great, they decrease the activity and stability of the hydrogenising catalysts. We studied the possibility of applying synthetic $\mathrm{NaX}$ and CaX type zeolites with different binders for selective purification of the refined miscella and cottonseed oil. For the quantitative evaluation of refining the miscella by zeolits, we used the spectral method of area comparison. The presented results show that the maximum effect lighted by gossypol, karotinoid and their derivatives reach to the synthetic zeolits $\mathrm{NaX}$ (kaolinite as a binder). So, this process can be applied in both refining and hydrogenation production.
\end{abstract}

UDC Number: 665.3.011.002. 5, DOI: 10.12955/cbup.2013.62

Keywords: cotton oil, zeolits, refining, hydrogenation, gossypol

\section{Introduction}

Solid fats for different purposes are mainly obtained by the hydrogenation of plant oils. As Nourooz and Appelqvist (1992) write, plant oils, particularly cottonseed oil, are glycerine and fatty acid esters. However, in addition to triacylglycerol, many related substances are extracted into oil content; their amount and quality depend on the oil production method. O'Brien (2005) gives basic information on the qualitative and assay content of related substances in different natural fats and oils.

The technology enables hydrogenation in the process of refining plant oils so as the content of related substances is reduced. Alkaline reagents are mainly used in this process. However, some substances incidental to the oil and the solvent (if used) do not react with alkali and form new complex compounds which pass into the hydrogenated oil. Although there seem not to be too many of them, but they significantly reduce the activity and stability of hydrogenation catalysts (Arutyunyan et al., 2004; Canessa \& Brozzetti, 2000).

Seed oil and fat refining is intended to temper triacylglycerols contained therein. However, the current methods of cottonseed oil refining do not always allow profound removing of related substances which are catalytically toxic. Their presence in the hydrogenated substance drastically decreases the catalyst activity and stability. They also affect the quality of the hydrogenation product. Solving these 
problems requires both a separate study of each material component incidental to the plant oil and assessment of their impact on hydrogenation of triacylglycerols.

The cottonseed oil differs from natural oils with extra content of gossypol and its derivatives (Rossi et al., 2003). Gossypol contains the following derivatives: combined gossipol, gossipurpurin and gossiverdurin which are classified as poisonous substances When storing oleaginous seeds and extracting oil under moisture and heat, gossypol partially binds to proteins, amino acids and phosphatides, thereby loses reactivity and toxicity, and goes into derivatives that do not contain free aldehyde groups and are colored from yellow to black: gossifulvin, gossikaerulin, etc. That is probably why extraction oil, containing gossypol alteration and transformation products, is considered the most complicated raw material for refinery. The presence of altered and combined forms of gossypol makes it difficult, and sometimes impossible, to obtain white oil with color index of 8-10 of red units at 35 of yellow ones by alkali refining. Being fairly acidiferous, gossypol reacts as aldehyde and polyphenol, thereby cuts the triacylglycerols hydrogenation rate. Besides the mentioned components incidental to plant oils, they also contain pigments: chlorophyll and carotenoids (Rafalson, 1986) That paper also points out that the remains of sodium soaps (soap stock) pass into the content of the refined oil being hydrogenated, due to technological failures or imperfections; this negatively affects the activity and other indicators of the catalyst being used.

Related substances contained in the solvent also play an important role. This especially applies to sulfur, phosphorus and other compounds contained in industrial solvents (extraction gasoline, hexane, petroleum solvent, etc.) used in oil extraction production.

Abdullaev, Mazhidov and others (1980) examine the influence of the purification of soybean oil triacylglycerols, as well as the influence of adding some other substances, on the rate and selectivity of the refine soybean oil hydrogenation. It has been revealed that oil re-refining and bleaching lead to an increase in the hydrogenation rate, and the chromatographic purification at $\mathrm{Al}_{2} \mathrm{O}_{3}$, subsequent to the re-refining, increases the hydrogenation rate yet more.

In the patent (Hdanov, Hvoschev \& Samulevich, 1981), the oil and fat purifying method is protected, which provides for mixing the fat or oil with a finely divided solid adsorbent which is capable of adsorbing different coloring impurities and oxygen-containing gases, etc. The catalyst and the adsorbent are removed by electro-filtration. Non-spherical pellets of a chemically inert material, which includes at least one mineral comprising the $\mathrm{SiO}_{2}$ crystal, are used for creating the filter bed. There may be different operating sequences in this method. One of them, for example, is mixing the refined oil and the adsorbent with the catalyst prior to hydrogenation and the subsequent electro-filtration of the hydrogenation product.

For oil and fat purification, Hdanov, Hvoschev and Samulevich (1981) recommend using, prior to hydrogenation, $0.01 \%$ of fine solid adsorbents such as discoloring clay fuller's earth, activated carbon, diatomaceous earth, etc. When carrying out the cottonseed oil hydrogenation alloy fixed-bed catalysts, Martucci, Annalisa and others (2012) employ a separate adsorber filled with activated carbon. The oil goes through the adsorber, gets refined (color, acidity etc. are improved) and goes to the column reactor where it undergoes hydrogenation. This process structuring has allowed increasing of the selectivity and stability of triacylglycerol saturation.

As Moschenskiy (2007) notes in his paper, the greatest effect of lightening is provided by different groups of natural clays - kaolin, halloysite, flask sorts on different fields. To improve the sorption capacity, they were used after thermal activation. In recent years, synthetic zeolites, which have 
unsurpassed selective capacity to absorb various substances, have become more often used as adsorbents in the catalyst systems.

\section{Materials and research methods}

\section{Raw materials}

The refined cottonseed oil and miscella made at JV "Toshkent Yog'-moy Kombinati" ("Tashkent oil factory") were used as a raw material. The followings underwent purification: the cottonseed oil of $109.3 \% \mathrm{~J}_{2}$ of iodine value (IV), $0.2 \mathrm{mg} \mathrm{KOH}$ of acid number (AN) and 5-11 red units of color value in a $13.5 \mathrm{~cm}$ sheet; the refined cotton miscella obtained after the separator with concentration of $53.0 \%$, 0.4-0.5 mg KOH of AN, color value of 13-14 red units at 35 yellow ones in $13.5 \mathrm{~cm}$ sheet.

The color index of the cottonseed oil in the miscella was determined on a VNIIJ-16 tool by comparison. The oil absorption value of adsorbents was determined by the following formula (Abduraximov, Baxtiyarov et al., 1998):

$$
\mathrm{X}=\frac{P_{1}-\left(P_{2}+P\right)}{P} 100
$$

where $P_{1}$ is the weight of the funnel with a filter, clay and absorbed oil, gr;

$\mathrm{P}_{2}$ is the weight of the funnel with a oil-impregnated filter, gr;

$\mathrm{P}$ is the weighed sorbent, gr.

Total sulfur content in the solvents and oil missella was determined by micro-method using the Raney catalyst. The differential thermal analysis (DTA) of adsorbents was carried out on the basis of the researches by Novikova, Adilova and Ryabova (1964). The method by Abduraximov, Baxtiyarov and others (1998) was employed to analyze the content of phosphatides, soap and other substances in the oil and miscella. The spectral-response characteristics of the oil and miscella were measured in the visible light region using the instrument Raduga-1 made by the "Khimavtomatika" research and production association.

\section{Zeolites}

Unlike activated carbon, zeolites are heteropolar ionic substances. Positive charges (small-radius cations, protonated hydrogen atoms of hydroxyl acidic groups) are concentrated on their surface. The affinity of zeolites for unsaturated organic compounds, polar molecules and others enables to remove organic sulfur compounds from solutions, and oxygen compounds from hydrocarbons. The advantage of zeolites is that they can be used to purify large amount of substances at low concentrations of zeolites. The chemical formula of a zeolite is as follows:

$$
\left(\mathrm{R}_{2} \mathrm{R}\right) \mathrm{OAl}_{2} \mathrm{O}_{3} \cdot \mathrm{n} \mathrm{\textrm {SiO } _ { 2 }} \cdot \mathrm{mH}_{2} \mathrm{O}
$$

where $\mathrm{R}_{2}$ is a component monovalent cation $\left(\mathrm{Na}^{+}, \mathrm{K}^{+}, \mathrm{Li}^{+}\right)$;

$\mathrm{R}$ is a component bivalent cation $\left(\mathrm{Ca}^{+2}, \mathrm{Ba}^{+2}\right.$ etc.);

$\mathrm{m}, \mathrm{n}$ are coefficients expressing the ratio of $\mathrm{SiO}_{2}: \mathrm{Al}_{2} \mathrm{O}_{3}$ (from 2 to 10 ). 
Petrenko (1971) reports on the use of zeolites in the fat purification by separation of oleins and trioleins. It is shown that zeolites with a pore diameter of from 3 to $15 \AA$ can absorb free fatty acids, water, mucus, phosphatides, colorants, flavorings and odorants. The most satisfactory results are obtained when using $\mathrm{X}$ and $\mathrm{Y}$ type zeolites with a pore diameter of 8-9 $\AA$. Zeolites do not display isomerizing capacity of triacylglycerols.

The oil and fat purification can be performed in one, two or more adsorbers using various sorts of zeolites, depending on the purpose. Methanol, propanol, hexane, sulfuric ether, etc. can be used as a zeolites recovery solvent (Petrenko, 1971). As it is well-known, only those molecules whose effective diameter is less than the diameter of holes in zeolite caves can penetrate zeolites through those holes. This explains the selective effect of molecular sieves. The analysis of various zeolite sorts has shown the possibility of using them for the selective extraction of certain groups of related catalytically toxic substances from plant oils. The $\mathrm{X}$ type zeolites, irrespective of the $\mathrm{SiO}_{2}: \mathrm{Al}_{2} \mathrm{O}_{3}$ ratio, are of main interest for this process: $\mathrm{Al}_{2} \mathrm{O}_{3}$.

\section{Laboratory unit for the selective thorough purification and hydrogenation of oils and miscella}

The scheme of the laboratory unit for the selective dynamic thorough purification of refined cottonseed oil (or miscella) in a fixed adsorbent bed is shown in Figure 1. The operation concept of this unit is as follows:

Figure 1: The laboratory unit for the selective dynamic thorough purification of refined cottonseed oil (or miscella) in a fixed adsorbent bed

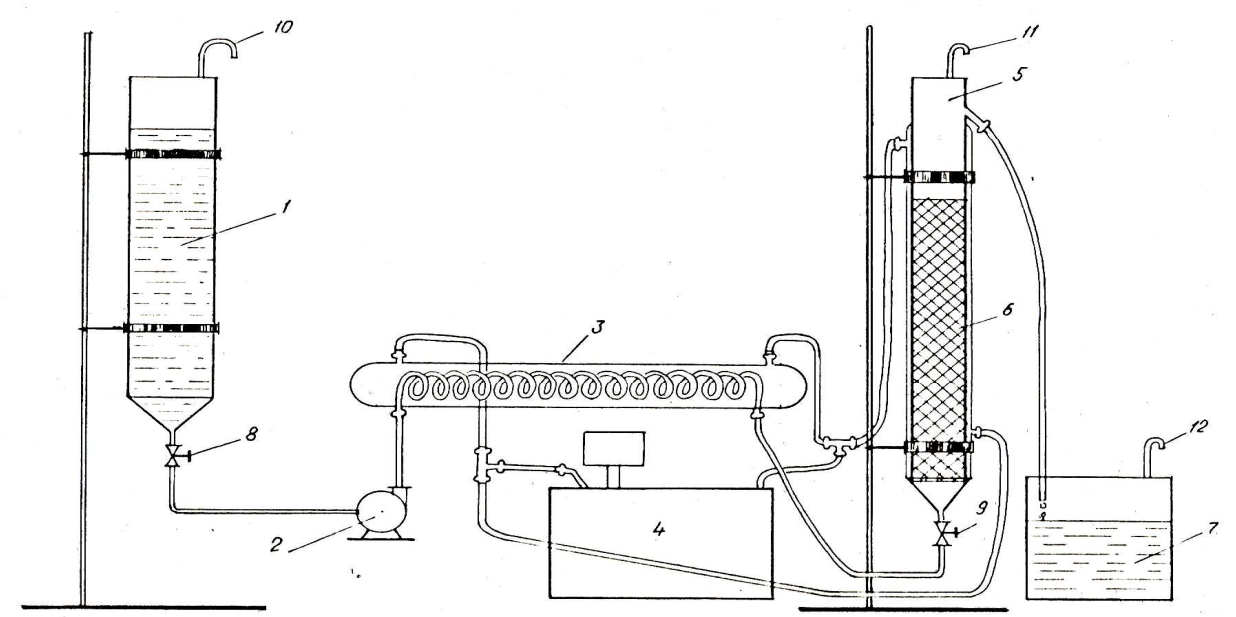

1 - Collector; 2 - Pump; 3 - Heater; 4 - Laboratory Thermostat; 5 - Adsorber; 6, 8, 9 - Valves; 10, 11,12 - venting lines

Source: Authors

The refined cottonseed oil (or miscella) is delivered, by the pump 2, from the collector 1 to the heater 3 where it is heated to $50-60^{\circ} \mathrm{C}$. The heated oil (or miscella) comes to the glass adsorber 5 , where it undergoes a selective thorough purification from harmful substances in the zeolite bed. The refined oil (or miscella) goes from the adsorber 5 to the purified miscella collector 7, from which it is directed to 
hydrogenation. The temperature in the heater 3 and the absorber 5 is controlled by the laboratory thermostats 4 . The purified oil (or miscell) flow in the collector 1 and adsorber 5 is controlled by valves 8 and 9 , respectively.

Lines 10, 11 and 12 serve for venting air-steam mixture generated during the experiment.

The present unit is designed to provide the basic indicators characterizing sorbents under dynamic conditions.

The complexity of cotton miscella and oil requires the development of effective refining methods, especially prior to the hydrogenation and interetherification stage. The existing methods for refining cottonseed oil and miscella are not perfect since they do not provide the desired depth of refinement. The adsorption refining of cottonseed oil or miscella is one of the most promising refining methods since enables to selectively extract the unwanted impurities. The practical processes of bleaching the refined cottonseed by clays and carbon are intermittently carried out using a time-consuming operation of oil filtration. Moreover, the moving of adsorbent particles in the refined oil content complicates subsequent stages of its processing.

In this context, it seems more rational to purify the refined miscella and cottonseed oil in a fixed adsorbent bed that perfectly blends with their subsequent hydrogenation using fixed-bed catalysts.

In the adsorption by polar sorbents, polar molecules from a non-polar solvent are better adsorbed. Therefore, the use of zeolites $/\left(\mathrm{R}_{2}{ }^{1} \mathrm{R}\right) \mathrm{OA} \mathrm{I}_{2} \mathrm{O}_{3} \mathrm{SiO}_{2} \bullet \mathrm{H}_{2} \mathrm{O} /$ with shape selective properties enables to selectively remove harmful substances contained in both oil and solvent.

We have studied the possibility of using $\mathrm{NaX}$ and $\mathrm{CaX}$ type synthetic zeolites with different binders for selective purification of the refined miscella and cottonseed oil. Also, using the DTA method, we revealed the best modes of their heat drying and activation. The obtained results are presented in Table 1.

As can be seen from Table 1, it is appropriate to maintain the zeolite drying and activation temperature at $350^{\circ} \mathrm{C} \div 400^{\circ} \mathrm{C}$, as thus its adsorption properties are completely restored. The $\mathrm{NaX}$ and $\mathrm{CaX}$ type synthetic zeolites adsorb just those substances whose critical diameter is less than the effective diameter of their pores. The effective pore diameter is $8 \div 10 \AA$ for CaX type, and $9 \div 13 \AA$ for NaX type.

Table 1: The DTA results for the examined zeolite specimens

\begin{tabular}{|l|l|r|r|r|}
\hline \multirow{2}{*}{ Zeolite type } & Zeolite form & \multicolumn{3}{|l|}{ Temperature of endothermic effect I, II and III, ${ }^{0} \mathrm{C}$} \\
\cline { 3 - 5 } & & I- effect & II- effect & III- effect \\
\hline $\mathrm{CaX}$ (kaolinite) & Granule & 230 & 280 & 910 \\
\hline $\mathrm{CaX}$ (bentonite) & $\begin{array}{l}\text { comminuted } \\
\text { granule }\end{array}$ & 235 & 285 & 915 \\
\hline $\mathrm{NaX}$ (kaolinite) & $\begin{array}{l}\text { comminuted } \\
\text { granule }\end{array}$ & 235 & 290 & 920 \\
\hline $\mathrm{NaX}$ (cement) & Granule & 240 & 300 & 930 \\
\hline Source: Authors & & & \\
\hline
\end{tabular}




\section{Results and conclusions}

The process of adsorption refining of cotton miscella in a fixed zeolite bed was carried out by means of a column unit at a temperature of $60{ }^{\circ} \mathrm{C}$, with the ratio of the adsorbent bed height to the diameter equal to 8 and the fresh feed rate of $0.4 \mathrm{~cm} / \mathrm{sec}$. The refined cotton miscella (Table 2) and oil (Table 4) underwent the selective purification.

Table 2: The variation of the refined cotton miscella parameters before and after the selective zeolite refining

\begin{tabular}{|c|c|c|c|c|c|c|}
\hline \multirow[b]{2}{*}{$\begin{array}{l}\text { Miscella } \\
\text { type }\end{array}$} & \multicolumn{6}{|c|}{ Refined cotton miscell indicators } \\
\hline & $\begin{array}{c}\text { Acid } \\
\text { number, } \\
\text { mg KOH }\end{array}$ & $\begin{array}{c}\text { Color value, } \\
\text { red units }\end{array}$ & $\begin{array}{c}\text { Phosphatide } \\
\text { content, \% }\end{array}$ & $\begin{array}{c}\left.\text { Total }^{*}\right) \\
\text { gossypol } \\
\text { content, \% }\end{array}$ & $\begin{array}{c}\text { Peroxide } \\
\text { number, } \\
\% \mathrm{~J}_{2}\end{array}$ & $\begin{array}{c}\text { Soap } \\
\text { content } \\
\%\end{array}$ \\
\hline \multicolumn{7}{|c|}{ CaX type zeolite (kaolinite as a binder) } \\
\hline $\begin{array}{l}\text { Before } \\
\text { refining }\end{array}$ & 0.4 & 13.0 & 0.06 & 0.08 & 0.025 & 0.002 \\
\hline $\begin{array}{l}\text { After } \\
\text { refining }\end{array}$ & 0.2 & 8.0 & 0.00 & 0.00 & 0.010 & $\begin{array}{c}\text { not } \\
\text { available }\end{array}$ \\
\hline \multicolumn{7}{|c|}{ NaX type zeolite (kaolinite as a binder) } \\
\hline $\begin{array}{l}\text { Before } \\
\text { refining }\end{array}$ & 0.5 & 14.0 & 0.08 & 0.09 & 0.030 & 0.003 \\
\hline $\begin{array}{l}\text { After } \\
\text { refining }\end{array}$ & 0.3 & 6.0 & 0.00 & 0.00 & 0.010 & $\begin{array}{c}\text { not } \\
\text { available }\end{array}$ \\
\hline \multicolumn{7}{|c|}{$\mathrm{NaX}$ type zeolite (cement as a binder) } \\
\hline $\begin{array}{l}\text { Before } \\
\text { refining }\end{array}$ & 0.4 & 13.0 & 0.08 & 0.09 & 0.088 & 0.002 \\
\hline $\begin{array}{l}\text { After } \\
\text { refining }\end{array}$ & 0.3 & 10.0 & 0.00 & 0.00 & 0.009 & $\begin{array}{c}\text { not } \\
\text { available }\end{array}$ \\
\hline
\end{tabular}

As can be seen from Table 2, maximum effect is observed in NaX type with kaolinite as a binder, where the acid number dropped to $0.2 \mathrm{mg} \mathrm{KOH}$, the color value reduced by 8 red units, the peroxide number dropped to $0.01 \%$ and the soap, the gossypol derivatives, reduced almost to zero.

Replacing a kaolinite binder with a cement one increases the oil color value. A similar case is observed when replacing the zeolite cation $\mathrm{Na}^{+}$with $\mathrm{Ca}^{++}$.

To quantify the degree of purification of the miscell zeolites used the spectral method of area comparison was used for quantitative evaluation of the degree of miscella refining by zeolites (Figure 2). For this purpose, the visible light region was divided into two segments ( $A B$ and $D B$ ), where oil related substances mainly became apparent. 
Figure 2: The relationship of variation in the transmission coefficient of the cottonseed miscella to the visible light wave length and the nature of the adsorbent used in its refining

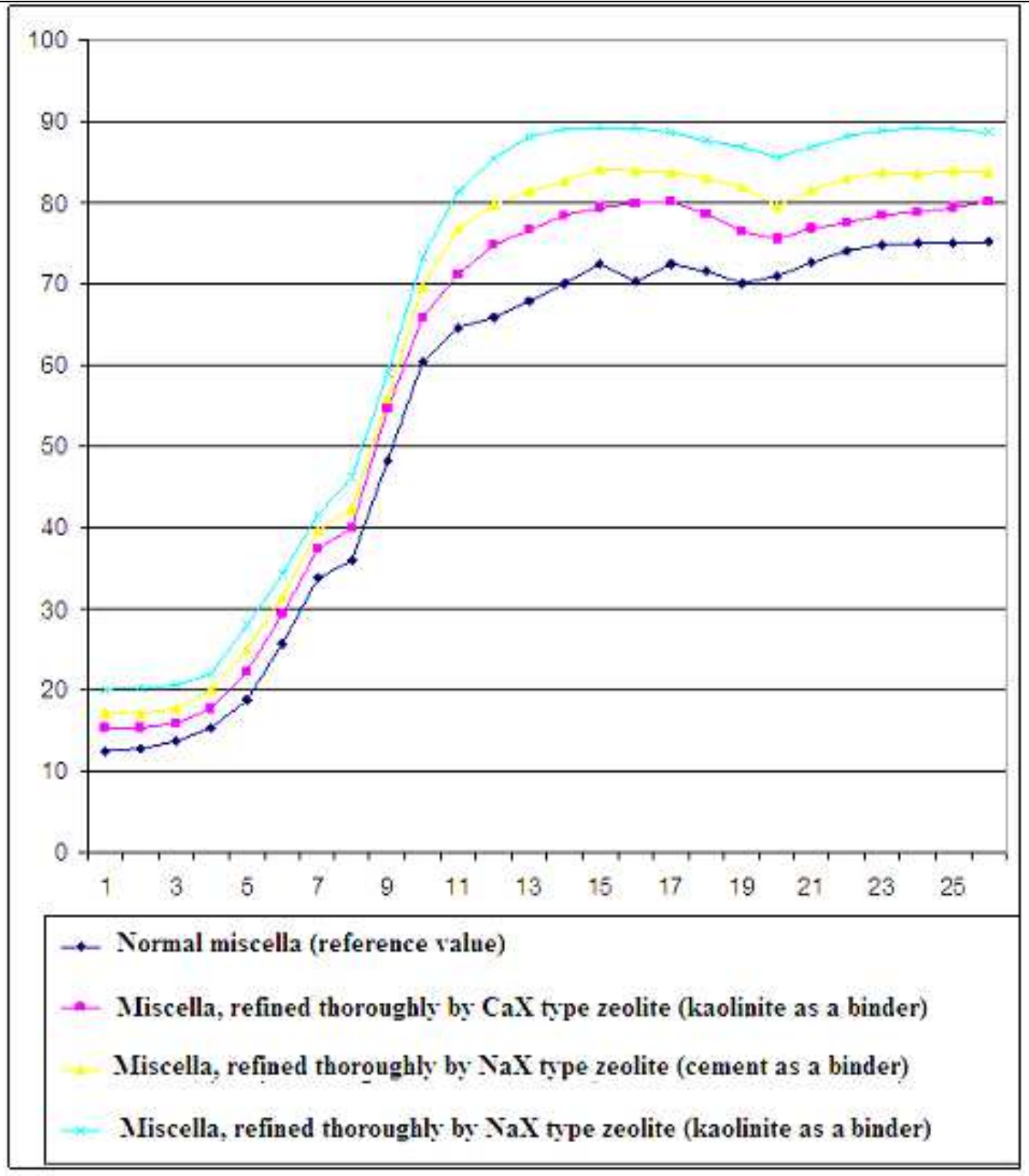

Source: Authors

Table 3: The evaluation of the purification level of the refined cotton miscella depending on the nature of adsorbent

\begin{tabular}{|l|r|r|r|}
\hline Miscella type & \multicolumn{1}{|l|}{ Area } & Area weight & Purification level \\
\hline By gossypol, carotenoids and their derivatives & \\
\hline Unrefined miscella & $\mathrm{ABCV}$ & 0.0576 & \\
\hline $\begin{array}{l}\text { Miscella, refined by CaX } \\
\text { (kaolinite as a binder) }\end{array}$ & $\mathrm{ABC} \mathrm{V}^{\mathrm{I}}$ & 0.0720 & $\frac{A B V^{I} C^{I}}{A B C V}=1.2500$ \\
\hline
\end{tabular}




\begin{tabular}{|c|c|c|c|}
\hline $\begin{array}{l}\text { by } \mathrm{CaX} \text { (cement as a } \\
\text { binder) }\end{array}$ & $\mathrm{ABC}^{\mathrm{II}} \mathrm{V}^{\mathrm{II}}$ & 0.0791 & $\frac{A B C^{I I} V^{I I}}{A B C V}=1.3732$ \\
\hline \multicolumn{4}{|c|}{ By chlorophyll, pheophytins etc. } \\
\hline Unrefined miscella & BDEC & 0.5307 & - \\
\hline $\begin{array}{l}\text { Miscella, refined by } \mathrm{CaX} \\
\text { (kaolinite as a binder) }\end{array}$ & $\mathrm{BDE}^{\mathrm{I}} \mathrm{C}^{\mathrm{I}}$ & 0.5480 & $\frac{B D E^{I} C^{I}}{B D E C}=1.0344$ \\
\hline $\begin{array}{l}\text { Miscella, refined by } \mathrm{NaX} \\
\text { (cement as a binder) }\end{array}$ & $\mathrm{BDE}^{\mathrm{II}} \mathrm{C}^{\mathrm{II}}$ & 0.5553 & $\frac{B D E^{I I} C^{I I}}{B D E C}=1.0463$ \\
\hline $\begin{array}{l}\text { Miscella, refined by } \mathrm{NaX} \\
\text { (kaolinite as a binder) }\end{array}$ & $\mathrm{BDE}^{\mathrm{II}} \mathrm{C}^{\mathrm{IIII}}$ & 0.5947 & $\frac{B D E^{I I I} C^{I I I}}{B D E C}=1.1205$ \\
\hline $\begin{array}{l}\text { Miscella, refined by } \mathrm{NaX} \\
\text { (kaolinite as a binder) }\end{array}$ & $\mathrm{ABC}^{\mathrm{III}} \mathrm{V}^{\mathrm{III}}$ & 0.0863 & $\frac{A B C^{I I I} V^{I I I}}{A B C V}=1.4982$ \\
\hline $\mathrm{rc}$ & & & \\
\hline
\end{tabular}

As seen from these results, maximum bleaching effect by gossypol, carotenoids and their derivatives is obtained by refining using $\mathrm{NaX}$ type synthetic zeolite (kaolinite - as a binder). When using the same type zeolite with cement as a binder, the purification level by these substances is 1.3732 , and when using the CaX type zeolite with kaolinite as a binder the level is 1.2500 . There is some smaller level of purification by these sorbents of related substances of chlorophyll group. For example, CaX type (kaolinite as a binder) purifies the refined miscella from chlorophyll group substances by 1.0344 times, $\mathrm{NaX}$ type (cement as a binder) by 1.0463, and $\mathrm{NaX}$ type (kaolinite as a binder) by 1.1205 times.

These data cannot fully characterize the properties of the studied adsorbents, but still allow determining their effect on certain groups of substances related to cottonseed oil, which is very important for the correct selection of the adsorbent. The efficient ratio of the zeolite bed height to the column unit diameter $(\mathrm{H} / \mathrm{d})$ has been experimentally determined, which is equal to $7 \div 8$. The nature of the hydrocarbon solvent also affects the quality of the refined cotton miscella being purified.

Similar results were obtained when purifying the refined cottonseed oil by $\mathrm{NaX}$ type zeolite (kaolinite as a binder) under steady-state conditions (Table 4).

Table 4 . The variation of the refined cottonseed oil parameters before and after purification by $\mathrm{NaX}$ type zeolite (kaolinite as a binder)

\begin{tabular}{|l|lr|lr|}
\hline \multirow{2}{*}{$\begin{array}{l}\text { The physical and chemical } \\
\text { features of cottonseed oil }\end{array}$} & \multicolumn{4}{|l|}{ Parameters of the refined cottonseed oil } \\
\cline { 2 - 5 } & before purification & \multicolumn{2}{l|}{ after purification } \\
\hline $\begin{array}{l}\text { Color value, red units at } 35 \\
\text { yellow units }\end{array}$ & 14.0 & 8.0 \\
\hline Acid number, mg KOH & 0.4 & & 0.2 \\
\hline
\end{tabular}




\begin{tabular}{|l|r|r|}
\hline Phosphatide content, \% & 0.05 & 0.02 \\
\hline Soap content, \% & 0.006 & not available \\
\hline Gossypol derivatives content & 0.03 & 0.04 \\
\hline Moisture content, \% & 0.15 & 0.01 \\
\hline Peroxide number, \% $\mathrm{J}_{2}$ & 0.03 & 53.9 \\
\hline Fatty acid content, \% & 54.5 & 18.0 \\
- linoleic $\left(\mathrm{C}_{18: 2}\right)$ & & 3.0 \\
\hline - oleic $\left(\mathrm{C}_{18: 1}\right)$ & 18.0 & 24.3 \\
\hline - stearic $\left(\mathrm{C}_{18: 0}\right)$ & 3.1 & 0.8 \\
\hline - palmitic $\left(\mathrm{C}_{16: 0}\right)$ & 23.5 & 109.3 \\
\hline - palmitoleic $\left(\mathrm{C}_{16: 1}\right)$ & & 0.9 \\
\hline Iodine value, $\mathrm{J}_{2} / 100$ gr & 109.5 & \\
\hline Source: Authors & & \\
\hline
\end{tabular}

As can be seen from Table 4, purifying the refined cottonseed oil in a bed of granulated NaX type zeolite (kaolinite as a binder) allows reducing the content of substances related to triacylglycerols that negatively affect the stability of the its subsequent processing. In the fatty acid content of cottonseed oil, we can notice that changes are observed by certain types of fatty acids, which indicates their affinity for this zeolite.

The studies have shown the possibility of multiple uses of $\mathrm{NaX}$ or $\mathrm{CaX}$ type zeolites in column apparatuses for refining cottonseed oil and miscella by their recurrent thermal recovery.

Therefore, this process can be implemented in both refining and hydrogenation production. At that, the preference should be given to $\mathrm{NaX}$ type zeolite (kaolinite as a binder).

\section{Conclusion}

The development of technology for the refined cotton miscella hydrogenation with the preliminary thorough purification in a fixed synthetic zeolite bed requires practical and factory testing of processing methods obtained in the laboratory. However, it is important to try to conduct the testing in conditions as close to industrial ones as possible which is essential for the development and implementation of the recommended technology.

The selective thorough purification of $52 \%$ industrial refined miscella, extracted from cotton seeds, has been carried out in a column adsorber in a fixed bed of granular synthetic $\mathrm{NaX}$ type zeolite (kaolinite as a binder). We have performed the zeolite activation in an oven at $350-400^{\circ} \mathrm{C}$ for 4 hours and then, having it cooled to $25-40^{\circ} \mathrm{C}$, put it into the column reactor by certain amounts ( 1 liter). The miscella was put to the bottom of the column. The purified miscella had an iodine value of $102.6 \% \mathrm{~J} 2$ and the following fatty acid content (\%): saturated acids - 26.3; oleic acid - 201; linoleic acid - 53.6. The oil color value in the miscella was equal to 16 red units at 35 yellow ones in $13.5 \mathrm{~cm}$ sheet. 
The volumetric flow rate of the miscella to the adsorber varied depending on the maximum removing of related substances, deactivating the catalyst. The experiments were conducted at a temperature of $60^{\circ} \mathrm{C}$.

When processing the refined cottonseed miscella in a fixed bed of synthetic NaX type zeolite (kaolinite as a binder), its qualitative parameters are significantly improved: the color value drops from 16 to 8 red units at 35 yellow ones in $13.5 \mathrm{~cm}$ sheet; the acidity drops to $0.1 \% \mathrm{KOH}$, and the content of phosphatides, soap, carotenoids, gossypol and its derivatives is reduced to 0 . The increase of peroxide value is not observed.

\section{References}

Abdullaev, N. S., Mazhidov, K. H., Abdurahimov, A. \& Hakimov, V. (1980). Issledovaniye protsessov adsorbsionnoy rafinatsii i gidrogenizatsii xlopkovogo masla na statsionarnom katalizatore [Study of the processes adsorption refining and hydrogenation of the cottonseed oil on stationary catalysts]. Jurnal Pischevaya promyshlennost [Journal of Food Industry], 1, pp.7-80.

Abduraximov, S., Baxtiyarov, S., Salimov, Z., Xatipov, B. \& Tillayeva, G. (1998). Otsenka stepeni osvetleniya masla i izbiratelnosti adsorbenta $\mathrm{k}$ soputstvuyushim triatsilglitserinam veshestvam [Estimation degrees of bleaching oil and selectivity to the accompanying triacylglycerols materials]. Uzbekskiy khimicheskiy jurnal [Uzbek Chemist Press], 1, 66-69.

Arutyunyan, N. S., Kornena, Y.P., Yanova, L. I, Zaxarova, I. I, Melamud, N. L, Martovshuk, Y. V., Krivova, A. Y. \& Arisheva, Y. A. (1998). Tehnologiya pererabotki jirov [Technology of the fat conversion]. (p. 117). Moscow, Russia: GIORD Press (Pischepromizdat).

Arutyunyan, N. S., Kornena, E. P. \& Nesterova, E. A. (2004). Rafinatsiya masel i jirov: teoreticheskiye osnovi, praktika, tehnologiya, oborudovaniye [Refining oil and fat. Theoretical bases, practice, technology, equipment]. (p. 288). Moscow, Russia: GIORD Press.

Canessa, C. E. \& Brozzetti, A. J. (2000). Process and composition for refining oils using metalsubstituted silicaxerogels. Canada Patent CA 2340098. Wilmington, DE: Pq Holding.

Gunstone., F. D. (2002). Vegetable Oils in Food Technology - Composition, Properties and Uses. (pp. 203-230). Oxford, UK: Blackwell Publishing. ISBN 1-84127-331-7

Hdanov, S. P., Hvoschev, S. S. \& Samulevich, N. N. (1981). Sinteticheskiye tseoliti: Kristallizatsiya, strukturno-himicheskoye modifitsirovaniye I adsorbtsionniye svoystva [Syntetic zeolits: crystallization, structured-chemical modify and adsorption characteristic]. Moscow, Russia: The Chemistry Press.

Martucci, A., Pasti, L., Marchetti, N., Cavazzini, A., Dondi, F. \& Alberti, A. (2012). Adsorption of pharmaceuticals from aqueous solutions on synthetic zeolites, Microporous and Mesoporous Materials, 1, pp. 174-183. http://dx.doi.org/10.1016/j.micromeso.2011.07.009

Moschenskiy, Y. I. (2007). Strukturno-chuvstvitelnym metodomdifferentsialnogo termicheskogo analiza. Nanorazmernykh materialov dlya tekhnicheskikh i meditsinskikh tseley [Structured-sensitive method of the differential thermal analysis. Nano-scaled materials for technical and medical purpose]. (pp. 230-232). Tolyatti, Russia: Tolyatti University. 
Tagliabue, M., Rizzo, C., Onorati, N. B., Gambarotta, E. F., Carati, A. \& Bazzano, F. (2012). Regenerability of zeolites as adsorbents for natural gas sweetening: A case-study. The Fuel Journal, 93, 238-244. http://dx.doi.org/10.1016/j.fuel.2011.08.051

Nourooz-Zadeh, J. \& Appelqist, L. A. (1992). Isolation and quantitative determination of sterol oxides in plant-based foods: soybean oil and wheat flour. J Am Oil Chem Soc, 69, $288-293$. http://dx.doi.org/10.1007/BF02635903

Novikova, O. S., Adilova, T. T. \& Ryabova, N. D. (1964). Ispolzovaniye dannyh differentsialnotermicheskogo analiza dlya harakteristiki mineralnih adsorbentov [Using the differential thermal analysis data for characterizing of mineral adsorbents]. The Uzbek Chemical Journal, 4, 43-46.

O’Brien, R. D. (2005). Cottonseed oil. In: Shahidi, F. (Ed.) (2005). Bailey's Industrial Oil and Fat Products, 2, 173-280.

Petrenko, D. S. (1971). Neorganicheskiye ionity i ikh ispolzovaniye [Zeolits and their usage]. Kiev, Ukraine: Kiev Press.

Rafalson, A. B. (1986). Rafinatsiya i gidrogenizatsiya rapsovogo masla [Refining and hydrogenation of the rapeseed oil]. Agropromizdat, 1, pp. 86.

Rossi, M., Gianazza, M., Alamprese, C. \&, Stanga, F. (2003). Food Chemistry, [August].8, pp. 291296. http://dx.doi.org/10.1016/S0308-8146(02)00551-4 